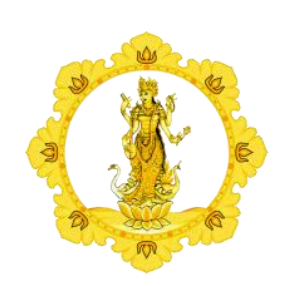

KALANGWAN

JURNAL PENDIDIKAN AGAMA, BAHASA DAN SASTRA

Vol. 10 No. 1 Maret 2020

\begin{tabular}{|l|l|l} 
p-ISSN : 1979-634X & e-ISSN : 2686-0252 & http://ejournal.ihdn.ac.id/index.php/Kalangwan
\end{tabular}

\title{
MAKNA ETIKA SEBAGAI LANDASAN MENTAL SPIRITUAL PENDIDIK YANG PROFESIONAL DI ZAMAN MILENIAL
}

\author{
Oleh : \\ I Made Putra Aryana \\ Institut Hindu Dharma Negeri Denpasar \\ E-mail: madeputra84@gmail.com
}

Diterima 22 Januari 2020, direvisi 11 Pebruari 2020, diterbitkan 31 Maret 2020

\begin{abstract}
This article describes educators in applying ethics as spiritual mental foundations in the millennial period. Discussing the importance of ethics as the mental and Spiritual foundation of Hindu educators to control emotions and behaviours in carrying out the duties of education and teaching in the millennial age. Discussed using observation methods, literature studies and interviews. The attitude of a professional educator, which is avoiding the prohibition of Hindu religion that can inhibit the development of professional and student development. Based on the analysis, a profesioteenic education in the millennial period is obliged to uphold ethics as the foundation of its spiritual spirituality. The Foundation has Hindu teachings, such as Panca Sraddha, Catur Purusa Artha, Trikaya Parisudha, Dharma Laksana.
\end{abstract}

Keywords: mental spiritual, professional educators, millennial age.

\section{PENDAHULUAN}

Pendidik dalam Kamus Besar Bahasa Indonesia (1991: 232), pendidik berasal dari kata "didik". Jadi kata ini diberi awalan memaka menjadi "mendidik" yang artinya memelihara dan memberi latihan (ajaran, tuntunan, dan pimpinan) mengenai ahklak dan kecerdasan pikiran. Kemudian pendidik didefinisikan sebagai proses pengubahan sikap dan tata laku seseorang atau kelompok orang dalam usaha mendewasakan manusia melalui uapaya pengajaran dan pelatihan, serat proses, cara, dan perbuatan mendidik.

Dalam bahasa Inggris, pendidik atau education berasal dari kata educate atau mendidik, yang berarti memberi peningkatan 
(to elicit, to give rise to) dan mengembangkan (to develop, to evolve). Dalam perkembangan peradaban manusia, banyak pengertian, pandangan dan teori yang dikemukakan orang mengenai pendidikan. Sementari itu, pendidikan dalam bahasa Yunani (paedagogiek) atau dalam bahasa Inggris (pedagogy) yang berarti the study of education goals preceses. Pendidikan sebagai segala usaha orang dewasa dalam pergaulan dengan anak-anak untuk memimpin perkembangan jasmani dan rohaninya ke arah kedewasaan.

Menurut John Dewey dalam buku Psikologi Pendidikan (Pupu Saeful Rahmat: 2018), pendidikan adalah suatu proses pengalaman. Setiap manusia menempuh kehidupan fisik maupun rohani. Karena kehidupan adalah pertumbuhan maka pendidikan merupakan proses yang membantu pertumbuhan batin tanpa dibatasi oleh usia. Proses pertumbuhan merupakan proses penyesuaian pada setiap fase. Pertumbuhan peserta didik menghasilkan perkembangan pribadinya.

Pamdangan hidup dan tinjauan pendidik terhadap peserta didik dan perkembangannnya akan sangat menentukan hasil pendidikan. Secara kelompok, masyarakat atau suatu bangsa menjalankan usaha pendidikan menurut pandangan hidup dan harapannya terhadap individu dan masyarakat. Menurut Ki Hajar Dewantara, pendidikan adalah daya upaya untuk memajukan bertumbuhnya budi pekerti (kekuatan batin, karakter), pikiran (intelek), dan tumbuh anak untuk memajukan kehidupan peserta didik selaras dengan usianya.

Dalam pendidikan tuntunan diberikan oleh pendidik kepada pertumbuhan peserta didik untuk untuk memajukan kehidupannya. Pendidikan bermaksud menuntun segala kekuatan kodrati peserta didik untuk mencapai keselamatan dan kebahagiaan yang setinggi-tingginya. Pertumbuhan budi pekerti dan pikiran tubuh peserta didik dituntun menurut peranan kodrati peserta didik.
Sejalan dengan hal tersebut, UU RI no 20 Tahun 2003 tentang Sisdiknas menyatakan definisi pendidikan sebagai berikut.

Pendidikan adalah usaha sadar dan terencana untuk mewujudkan suasana belajar dan proses pembelajaran agar peserta didik secara aktif mengembangkan potensi dirinya untuk memiliki kekuatan spiritual keagamaan, pengendalian diri, kepribadian, kecerdasan, ahklak mulia, serta keterampilan yang diperlukan dirinya, masyarakat, bangsa, dan negara.

Menurut Jalaludin dan Adbdulah Idi dalam buku Filsafat Pendidikan: Manusia, Filasafat dan Pendidikan (2017), membahas bahwa filsafat pendidikan sebagai ilmu pengetahuan normatif dalam bidang pendidikan merumuskan kaidah-kaidah, norma-norma dan/atau ukuran tingkah laku perbuatan yang sebenarnya dilaksanakan oleh manusia dalam hidup dan kehidupannya.

\section{PEMBAHASAN}

\section{Pendidik sebagai Jabatan Profesional}

Pendidik memegang peranan penting dalam perkembangan peserta didik untuk mencapai keselamatan dan kebahagiaan serta mengajarkan keterampilan yang diperlukan bagi dirinya masyarakat, bangsa dan negara. Pendidik adalah manusia dewasa yang telah sadar akan kemanusiaannyadalam membimbing, melatih, mengajar, dan menanamkan nilai-nilai dan dasar-dasar pandangan hidup kepada generasi muda, agar nantinya menjadi manusia yang sadar dan bertanggung jawab akan tugas-tugas hidupnya sebagai manusia, sesuai dengan sifat hakiki dan ciri-ciri kemanusiannya. Dengan kata lain pendidik berusaha menjadikan peserta didik menjaadi pribadi yang bertanggung jawab.

Pendidik adalah orang dewasa yang berusaha memberikan pengaruh, perlindingan dan pertolongan yang tertuju pada pendewasaan peserta ddidik. Tugas pendidik adalah membantu atau menolong peserta didik agar cukup cakap dalam melaksanakan tugas hidupnya sendiri atas tanggung 
jawabnya sendiri. Pertolongan tersebut berifat rohani karena berupa bimbingan terhadap fungsi-fungsi rohani peserta didik, seperti akal, ingatan dan emosi, anak.

Ada beberapa hal yang perlu dipahami dengan baik dan benar secara filosofis dalam kaitannya dengan tatalaksana kehidupan bermasyarakat dan berorganiasi. Kehidupan bermasyarakat memiliki ciri-ciri, sifat, dan prilaku yang berbeda-beda. Semua itu bilamana diperhatikan tentu memiliki makna filosofis. Bagaimana masyarakat dapat bertindak dan berbuat dengan baik dan benar untuk mendapatkan kebahagian dan kedamaian secara umum.

Pekerjaan pendidik merupakan pekerjaan profesioanal. Sanjaya (2016: 1415) meguraikan syarat ciri pokok pekerjaan profesioanal adalah: 1). Ditunjang oleh suatu illmu tertentu, sehingga kinerjanya didasarkan oleh keilmuannya yang dapat dipertanggungjawabkan secara ilmiah. 2). Menekankan keahlian pada bidang tertentu yang spesifik. 3). Tingakat kemampuan dan keahliannya didasarkan pada latar belakang pendidikan sesuai dengan profesinya. 4). Memiliki dampak social kemasyarakatan dan memiliki kepekaan terhadap efek pekerjaan profesinya itu.

Seorang pendidik memiliki kewajiban untuk selalu menjaga tingkah lakunya sebagai tanggung jawabnya terhadap peserta didik. Pendidik wajib mengedepankan etika sebagai landasan spiritual dalam menjalankan kewajibannya sehari-hari. Berkaitan dengan hal tersebut maka penulis akan menguraikan etika Agama Hindu sebagai landasan mental spiritual dalam tulisan ini.

\section{Makna Etika Sebagai Landasan Mental Spiritual Pendidik Profesional}

Secara etimologi, etika berasal dari bahasa Yunani, ethos yang berarti watak kesusilaan atau adat. Dalam Kamus Besar Bahasa Indonesia etika diartikan ilmu pengetahuan tentang asas-asas akhlak (moral). Secara terminologi, etika mempunyai banyak ungkapan yang semuanya itu tergantung pada sudut pandang masingmasing ahli. Etika sebagai ilmu yang menjelaskan arti baik dan buruk, menerangkan apa yang seharusnya dilakukan oleh manusia di dalam perbuatan mereka dan menunjukkan jalan untuk melakukan apa yang seharusnya diperbuat. Etika sebagai filsafat nilai, kesusilaan tentang baik-buruk, serta berusaha mempelajari nilai-nilai dan merupakan juga nilai-nilai itu sendiri.

Ki Hajar Dewantara menjelaskan etika merupakan ilmu yang mempelajari soal kebaikan (dan keburukan) di dalam hidup manusia semuanya, teristimewa yang mengenai gerak gerik pikiran dan rasa yang dapat merupakan pertimbangan dan perasaan sampai mengenai tujuan yang dapat merupakan perbuatan. Austin Fogothey (seperti yang dikutip Ahmad Charris Zubair) mengatakan bahwa etika berhubungan dengan seluruh ilmu pengetahuan tentang manusia dan masyarakat sebagi antropologi, psikologi, sosiologi,ekonomi, ilmu politik dan hukum.

Dari beberapa definisi etika tersebut dapat segera diketahui bahwa etika berhubungan dengan empat hal sebagai berikut. (1) Dilihat dari segi obyek pembahasannya, etika berupaya membahas perbuatan yang dilakukan oleh manusia. (2) Dilihat dari segi sumbernya, etika bersumber pada akal fikiran atau filsafat. Sebagai hasil pemikiran maka etika tidak bersifat mutlak, absolute dan tidak pula universal. Ia terbatas, dapat berubah, memiliki kekurangan dan kelebihan. Selain itu etika juga memanfaatkan berbagai ilmu yang membahas prilaku manusia seperti ilmu antropologi, psikologi, sosiologi, ilmu politik, ilmu ekonomi dan sebagainya. Hal ini dimungkinkan, karena berbagai ilmu yang disebutkan itu sama-sama memiliki obyek pembahasan yang sama dengan etika, yaitu perbuatan manusia. (3) Dilihat dari segi fungsinya, etika berfungsi sebagai penilai, penentu dan penetap terhadap suatu perbuatan yang dilakukan oleh manusia, yaitu apakah perbuatan tersebut akan dinilai baik, buruk, mulia, terhormat, hina dan sebagainya. Dengan demikian etika lebih berperan sebagai konseptor terhadap sejumlah prilaku yang dilaksanakan oleh manusia. Peranan etika dalam hal ini tampak 
sebagai wasit atau hakim, dan bukan sebagai pemain. Ia merupakan konsep atau pemikiran mengenai nilai-nilai untuk digunakan dalam menentukan posisi atau status perbuatan yang dilakukan manusia. Etika lebih mengacu kepada pengkajian sistem nilai-nilai yang ada. (4) Dilihat dari segi sifatnya, etika bersifat relative yakni dapat berubah-ubah sesuai dengan tuntunan zaman.

Dengan ciri-cirinya yang demikian itu, maka etika lebih merupakan ilmu pengetahuan yang berhubungan dengan upaya menentukan perbuatan yang dilakukan manusia untuk dikatakan baik atau buruk. Berbagai pemikiran yang dikemukakan para filosof barat mengenai perbuatan yang baik atau buruk dapat dikelompokkan kepada pemikiran etika, karena berasal dari hasil berpikir. Dengan demikian etika sifatnya humanistis dan anthropocentris.

Pemahaman etika sebagai landasan mental spiritual dapat dipahami seperti berikut: Etika (Ethic = Bahasa Inggris) artinya, susila, kesusilaan, ilmu akhlak. Sila adalah salah satu kerangka dasar ajaran agama Hindu (Tattwa, Sila, Upacara) atau merupakan ajaran pertama dan utama dari Saptangga Dharma, yaitu:

1) Sila $=$ Kesusilaan.

2) Yadnya = Persembahan suci.

3) Tapa $=$ Pengendalian diri.

4) Dana $=$ Berderma.

5) Prawrjya = Menyebarkan Dharma.

6) Diksa = Upacara inisisi.

7) $Y o g a=$ Menunggalkan diri dengan Tuhan.

Pada Sloka Wrehaspati Tattwa no. 25 dijelaskan bahwa, "Sila ngaranya mangrakascara rahayu", yang artinya Sila adalah menjaga perilaku/kebiasaan agar tidak menyimpang dari norma-norma kebenaran dan kebaikan atau memelihara perangai yang baik dan benar menurut Dharma Agama dan sosial budaya. Suatu perilaku dikatakan etis apabila; sopan, pantas/wajar, baik, dan benar sesuai norma dan nilai yang berlaku. Sedangkan norma atau aturan tingkah laku yang baik dan mulia disebut Tata Susila.

Ajaran Hindu tidak memakai istilah dogmatik baik dan jahat atau surga dengan neraka melainkan memiliki etika-etika yang berdasar karena kebutuhan untuk menyelaraskan keinginan individu, emosi, dan ambisi untuk mengarahkannya pada sebuah kehidupan yang harmonis di bumi dengan tujuan mutlak dari agama Hindu untuk menyadari keberadaan kita sendiri. Kesadaran diri menurut pandangan Hindu adalah kesadaran pada diri kita dengan Tuhan, sebagai sumber dan intisari dari keberadaan manusia dan kebebasannya. Setiap individu yang terdiri dari tubuh fisik (sarira), pikiran (manas), intelek (buddhi), dan diri (atman).

Berdasarkan 4 (empat) hal tersebut di atas (sopan, pantas/wajar, baik, dan benar sesuai norma dan nilai yang berlaku), setiap individu membutuhkan hal-hal keduniawian (artha) untuk dapat mempertahankan tubuh fisik dan memuaskan segala kebutuhan keluarga dengan ketergantungannya. Untuk memuaskan pikiran dan intelek, kebutuhan untuk memenuhi keinginannya dan pengejaran intelek (kama) atau penyatuan dengan Tuhan merupakan tujuan utama dalam kehidupan manusia (moksha).

Setiap manusia harus memainkan perannya demi kebaikan masyarakat, bangsa, dan dunia dengan melakukan tindakan yang dimotivasi kebaikan sosial dan bertindak sesuai dengan batasan dharma (kebenaran), tugas, moral, dan hukum sosial. Sehingga dalam hal ini terdapat empat tujuan prinsip hidup manusia yaitu dharma, artha, kama, dan moksha. Dharma adalah yang pertama, yang menandakan bahwa ketiganya tidak dapat dipenuhi tanpa memenuhi kewajiban dharma. Moksha adalah tujuan yang terakhir karena keterikatan adalah memungkinkan ketika dari ketiga bagian lain sudah terpenuhi. Walaupun dharma memiliki arti yang berbeda dari sudut pandang etika, dharma adalah sistem moral dan nilai etika. Hindu Dharma menyadari adanya tujuh faktor yang membuat seseorang menyimpang dari jalan dharma atau mengarah untuk perbuatan dosa, yaitu: (1) penderitaan (tresna), (2) kemarahan (krodha), (3) ketamakan (lobha), (4) keterikatan (moha), (5) rasa bangga (mada), (6) kecemburuan (matsarya), dan ( 7) egoisme (ahankara). 
Untuk menghindari manusia tidak menyimpang karena pengaruh ketujuh faktor tersebut, maka di dalam filsafat Hindu terdapat sepuluh kebajikan, yang dikenal dengan "Dharma Laksana", yang terdapat di dalam kitab "Manu Smrti Dharmasastra" yaitu sebagai berikut:

a) Akrodha (tidak marah): Kemarahan yang menutupi alasan, menghasilkan perbedaan antara benar dan salah, serta kebajikan dan keburukan. Ketika pemikiran yang dapat membedakan itu dirusak maka orang tersebut akan kehilangan identitas diri. Seseorang yang marah akan menyakiti diri sendiri dan orang lain, dengan tiga cara yang berbeda secara fisik (melalui kekerasan), secara verbal (melalui kata-kata kasar), dan secara mental (melalui keinginan yang buruk). Pengendalian kemarahan dapat diartikan sebagai sebuah pemikiran yang baik dalam diri.

b) Asteya (tidak mencuri): Secara umum mencuri dapat didefinisikan sebagai mengambil dengan paksa atau dengan mengambil barang/benda milik orang lain. Dalam etika Hindu, mencuri juga termasuk di dalamnya ingin menguasai barang/benda orang lain dan di atas kebutuhan legistimasi yang menghambat kemajuan orang lain, atau mengambil kesempatan mereka dengan memiliki sesuatu melalui maksud yang ilegal. Kurangnya pengendalian indera dan ketamakan seseorang biasanya menimbulkan suatu keinginan untuk mencuri. Seseorang yang memegang teguh asteya akan bebas dari ketamakan dan tidak memiliki keinginan untuk mencuri.

c) Atma Vinigraha (pengendalian pikiran): Pikiran yang terganggu tidak dapat akan membedakan benar dengan yang salah atau kebaikan dengan keburukan. Konsentrasi dalam memberikan kebijaksanaan dan kasih yang mendalam dapat meningkatkan kekuatan pikiran.

d) Dama (pengendalian diri atau pengendalian indera): Indera harus dapat dikendalikan sehingga dapat berfungsi sesuai dengan pengarahan alasan. Pengendalian diri bukan tidak berarti penolakan diri namun dalam bersikap sederhana dalam memuaskan kebutuhan dan menghindari kebodohan. Seseorang yang dapat mengendalikan dan membebaskan dirinya dari berbicara yang lepas kendali, gosip, minum berlebihan, dan menjaga tubuh dan pikirannya agar terkendali. Kurangnya diskriminasi antara apa yang yang harus dan tidak harus dilakukan yang mengarahkan seseorang pada angan-angan. Sebuah pikiran yang berkhayal menjadi tidak sehat untuk dapat menyadari tujuan dari hidup seseorang.

e) Dhi (kemurnian pikiran): Kemurnian pikiran dan intelek adalah lebih penting daripada kecerdasan. Seorang manusia yang memiliki kemurnian intelek akan bebas dari rasa sakit, temperamen yang tidak baik, perasaan yang buruk, dan keinginan yang tidak dapat diduga. Para Rsi Hindu berpendapat bahwa kecerdasan sangat dianjurkan untuk pengajaran, agar melakukan perbuatan yang baik dan pikiran yang mulia serta meditasi yang teratur.

f) Dhrti (ketetapan dan persistence): Seseorang harus tetap dalam hal pendirian untuk dapat menemukan kebenaran. Pikiran yang selalu terus beriak tidak akan dapat menemukan kebenaran. Hidup yang benar sangat dimungkinkan hanya dengan komitmen seseorang untuk menjalankan kehidupannya.

g) Ksama (pengampunan atau kesabaran): Pengampunan adalah kebaikan yang utama dari moral dan etika hidup. Pengampunan dapat mempertahankan kesucian pikiran bahkan situasi yang provokatif dalam kehidupan seseorang.

h) Satya (kebenaran): Satya tidak berarti semata-mata berkata yang benar, perkataan dan perbuatan, dan dalam hubungan kita dengan orang lain. Untuk menjalankan kehidupan yang bermoral dan hidup yang beretika, maka seseorang harus melakukan kebenaran. Konsep dari moralitas dapat berubah setiap waktu, namun kebenaran tidak akan pernah 
berubah. Tidak ada seorangpun yang dapat menyembunyikan kebenaran secara terus menerus.

i) Sauca (kemurnian tubuh dan pikiran): Kemurnian itu terbagi dalam dua jenis yaitu fisik dan mental. Kemurnian fisik berarti menjaga tubuh seseorang bersih dari luar maupun dalam. Kebersihan diri dari dalam dapat diperoleh dengan menjalankan hukum kesehatan yang baik dan memakan makanan yang "sattvika" (makanan yang menyehatkan, kekuatan metal, kekuatan, panjang umur, dan yang bergizi serta mengandung nutrisi). Kebersihan luar artinya mengenakan pakaian yang bersih dan menjaga kebersihan tubuh. Kemurnian mental berarti bebas dari pemikiran yang negatif dari nafsu, ketamakan, kemarahan, kebencian, rasa bangga, kecemburuan, dan lain-lain.

j) Vidya (pengetahuan): Kitab Hindu menyatakan bahwa pengetahuan itu ada dua jenis yaitu pengetahuan yang lebih rendah (apara-vidya) dan pengetahuan yang lebih tinggi (para-vidya). Pengetahuan yang lebih rendah artinya pengetahuan yang bersifat keduniawian dalam bidang ilmu dan pengetahuan yang sangat diperlukan untuk kehidupan di dunia. Sedangkan pengetahuan yang lebih tinggi adalah pengetahuan spiritual yang mengajarkan cara untuk dapat mengatasi kesengsaraan yang tidak diharapkan, menggapai tujuan yang bukan halangan, serta mencapai kekuatan mental dan spiritual untuk dapat mengatasi perjuangan hidup. Pengetahuan spiritual dapat diperoleh melalui belajar kitab yang berhubungan dengan orang suci, dan dengan melakukan perbuatan yang tidak mementingkan diri (niskama). Pengetahuan spiritual juga dapat membantu seseorang untuk menjalankan kehidupan yang berarti, yang menguntungkan secara sosial. Tujuan pengetahuan spiritual ini adalah untuk mencapai penyatuan yang mutlak dengan Tuhan.
Dari fenomena tersebut di atas maka sangat erat hubungannya dengan sikap seorang pemimpin yang profesional, yakni menjauhi larangan-larangan yang dapat menghambat perkembangan peserta didik. Pendidik perlu memperhatikan etika, normanorma, dan perundang-undangan yang berlaku.

Agama Hindu seringkali dianggap sebagai agama yang beraliran politeisme karena memuja banyak Dewa, namun tidaklah sepenuhnya demikian. Dalam agama Hindu, Dewa bukanlah Tuhan tersendiri. Tuhan itu Maha Esa tiada duanya. Dalam salah satu ajaran filsafat Hindu, Adwaita Wedanta menegaskan bahwa hanya ada satu kekuatan dan menjadi sumber dari segala yang ada (Brahman), yang memanifestasikan diri-Nya kepada manusia dalam beragam bentuk.

Berdasarkan uraian tersebut di atas Agama Hindu memiliki lima dasar atau asas sebagai keyakinan dan kepercayaan, dimana keyakinan tersebut merupakan kekuatan moral pemeluk Agama Hindu yang disebut dengan Panca sradha. Panca sradha merupakan kepercayaan dan keyakinan dasar umat Hindu. Kelima keyakinan tersebut, yakni:

Widdhi sraddha sebagai dasar etika Hindu. Karena yakin bahwa Brahman (Tuhan) berada dimana-mana dan selalu ada serta Maha Tahu, mengetahui semua yang tampak dan tak tampak, maka menjadi alasan atau dasar yang mendorong orang untuk selalu menjaga perilakunya agar tidak menyimpang dari ajaran-ajaran Tuhan (Agama) dimana dan kapan pun, baik ada yang melihat maupun tidak. Walau hanya dalam angan atau pikiran saja semestinya tidak dibiarkan menyimpang karena Tuhan mengetahui apapun yang ada dalam pikiran manusia. Apalagi umat Hindu juga yakin bahwa Tuhan menyayangi orang-orang yang susila dan berbudi pekerti yang luhur. Uraian tersebut di atas, menggambarkan bahwa seorang pendidik yang profesional harus memiliki kepercayaan terhadap Tuhan yang Maha Esa. Seorang pendidik percaya dengan adanya kekuatan- 
kekuatan yang ada di luar dirinya, suksenya pelaksanaan tugas kependidikannnya merupakan kehendak Tuhan yang Maha Esa. Dalam agama Hindu pendidik Hindu bersama-sama peserta didik melaksanakan pemujaan terhadap Tuhan dalam manifestasinya sebagai Dewi Saraswati, dewannya ilmu pengetahuan rohani dan Dewa Ganesa, dewa pengetahuan di bidang kerohanian. percikan kecil yang ada dalam tubuh makhluk hidup yang memberikan kekuatan hidup pada setiap mahkluk, Maha Saksi yang tidak dapat ditipu, maka timbul etika tidak boleh bohong. "Sanghyang Atma sirata dewa ring sarira, manoning ala ayu tan keneng in imur-imur." Artinya, Sanghyang Atma adalah dewa dalam tubuh, mengetahui palsu dan sejati (baik-buruk) tak dapat dikelabuhi. Karena yakin bahwa pada dasarnya Atma semua makhluk adalah tunggal, tapi berbeda kondisinya karena karmanya dan tubuhnya masing-masing maka Hindu meyakini konsep "Bhineka Tunggal" artinya berbdea-beda satu sama lain namun pada hakekatnya tunggal. Berdasarkan kenyataan bahwa manusia keadaannya berbeda-beda, ada yang lebih tua, ada yang lebih muda, ada yang lebih tinggi statusnya, ada yang lebih rendah, maka orang bertata krama atau beretika; orang yang lebih rendah statusnya atau lebih muda umurnya patut menghormati yang lebih tinggi statusnya atau lebih tua umurnya, orang lebih tinggi statusnya atau lebih patut menghargai yang lebih rendah dan yang lebih muda. Berdasarkan keyakinan bahwa, pada hakekatnya semua Atma adalah tunggal, melahirkan filsafat "Tat Twam Asi" artinya dia adalah kamu: melandasi serta mendorong etika untuk saling menghargai satu sama lain. Tat Twam Asi juga landasan dasar salah satu ajaran etika Hindu: "Arimbawa" maksudnya punya pertimbangan kemanusiaan.

Sehubungan dengan tulisan, ini yakni etika dalam susila Hindu, maka seorang

pendidik mempunyai rasa kasihan, ingin menolong, dapat memaafkan, sehingga dalam memperlakukan atau menindak orang lain mengukur pada diri sendiri. Sebelum bertindak tanya dulu kepada diri sendiri "Bagaimana seandainya aku diperlakukan atau ditindak demikian?" Bila menimbulkan rasa tak enak, menyakitkan, maka sebaiknya orang tidak diperlakukan demikian: bila menyenangkan atau membahagiakan (dalam arti positif) sebaiknya dilakukan.

Karma Phala Sraddha. Karena yakin dengan Hukum Karma Phala (buah perbuatan) bahwa, setiap perbuatan pasti akan membawa akibat, maka orang menjaga sikap dan perilakunya agar selamat (anggraksa cara rahayu) termasuk menjaga pikiran. Bukan dalam tindakan saja juga dalam angan-angan atau pikiran saja juga berakibat atau berbuah seperti sloka berikut "Yadiastun riangen-angen maphala juga ika" (Kajeng, 2005) Artinya, walaupun baru hanya dalam pikiran akan membawa akibat itu. Dalam Kakawin Ramayana "Siapakari tan temung ayu masadana sarwa ayu, nyata katemwaning ala masadhana sarwa ala" Artinya, siapa yang tak akan memperoleh kebaikan bila sudah didasari dengan perbuatan baik Pastilah hal-hal yang buruk akan didapat bila didasari dengan perbuatan buruk. Keyakinan pada Karma Phala jelas menjadi dasar dan sekaligus kontrol dalam berpikir, berkata, dan berbuat. Demikianlah keyakinan pada Hukum Karma Phala menumbuhkan Etika Hindu yang perlu diteladani untuk menjalankan keawjiban dan tanggung jawab yang transparan.

Konsep ini sama dengan hukum sebab akibat (causal law). Selain bernilai etika moralis, juga mempunyai nilai filosofis yang mendalam. Konsep ini juga merupakan penuntun bagi setiap orang yang mempercayai hukum alam dan hukum yang dibuat oleh manusia sendiri. Bila seseorang menanam jagung, pasti akan memetik buah jagung pada saatnya. 
Bila seseorang berbuat baik, pasti ada saatnya yang tepat dia akan memetik hasil perbuatannya tersebut. Oleh karena itu, dalam agama Hindu terdapat konsep Tri Kaya Parisudha (tiga hal yang menyangkut kesucian / kebenaran), yakni: 'berpikir yang suci dan benar, berkata yang suci dan benar, dan berperilaku yang suci dan benar. Adanya Hukum Karma Phala menuntun kebanyakan pemeluk Agama Hindu untuk berbuat yang tidak merugikan orang lain termasuk pemeluk agama lain karena ada rasa kurang berani menerima akibat yang buruk bagi pelaku. Demikian juga seorang pendidik melaksanakan tugas dan kewajibannya dengan baik dan tidak berupaya merugikan orang lain.
Fenomena tersebut di atas merupakan simbolik suatu keprofesionalan dalam menjalankan tugas dan tanggung jawab pendidikan yakni sifat kewaspadaan terhadap situasi dan kondisi. Apabila dicermati secara simbolik unsur punarbhawa adalah penderitaan. Artinya seorang pendidik menanggung akibat dari perbuatan yang kurang baik, kurang profesional. Melakukan perbuatan yang tidak baik menyebabkan menemui penderitaan baik secara jasmani maupun rohani, oleh karena itu sangat perlu untuk mengindari perbuatan-perbuatan yang melanggar hukum. Pelanggaran hukum adalah pelanggaran etika, norma-norma, undang-undang dan lain sebagainya.

Akibat dari pelanggaran tersebut akan berdampak pada citra profesi pendidik dan organisasi yang dipimpinnya. Disamping itu berakibat pula terhadap diri sendiri baik secara fisik maupun mental. Secara fisik dikenakan hukuman badan atau hukuman penjara, sedangkan secara mental, seorang pendidik akan tertekan dengan perasaan kondisi dan situasi batin dan kadang-kadang berakibat patal.

e). Moksha Sraddha. Istilah moksha dalam Agama Hindu merupakan tujuan hidup beragama, berarti bebas dari semua keterbatasan, perbudakan dan ketidaksempurnaan. Moksha adalah suatu keadaan penyatuan dengan Tuhan yang merupakan hak setiap manusia. Sifat sejati jiwa manusia adalah bebas dan Illahi. Bagi manusia, kebebasan muncul dari pengetahuan tentang diri sejatinya (Swami Prabhavananda 2006:79).

Apalagi yakin dengan adanya moksha yang lebih tinggi lagi daripada surga yaitu menyatunya Atma dengan Brahman (Tuhan) bagi yang berhasil melepaskan diri dari belenggu papa dengan berbuat baik (subhakarma) menikmati "sat cit ananda" atau "suka tan pawali dukha", artinya suka yang tak akan pernah kembali menemukan duka, dengan kata lain mencapai kebahagiaan abadi. Seseorang akan dapat lepas dari lingkaran karma dan samsara apabila sanggup membuat 
hidupnya betul-betul suci. Makna etika atau sila memiliki makna untuk semakin menjauhkan orang dari neraka dan menghantarkan untuk semakin dekat dengan sorga dan moksha. Keyakinan ini mendorong orang untuk beretika, lebih semangat untuk menegakkan sila (susila) dalam hidupnya lebih-lebih menjadi seorang pendidik.

Dalam usaha mencapai moksha ini, kitab Bhagawat Gita (2004) telah menjelaskan bahwa jalan yang harus ditempuh ialah dengan melaksanakan yoga. Yoga dalam pengertiannya yang sederhana adalah usaha mendisiplinkan diri, tata cara meditasi, cara mengendalikan atau cara mengawasi. Dimaksudkan dengan mengendalikan maupun mengawasi dan menguasai kegiatan ingatan dan kegiatan indria serta melakukan tekanan terhadapnya.

Yoga terdiri atas dua tingkatan. Tingkatan pertama bersifat perbuatan lahir. Dan tingkatan kedua bersifat perbuatan batin. Kedua tingkatan itu adalah sebagai berikut.

\section{Kriya Yoga}

a) Yama-yoga, menahan diri untuk membunuh, berdusta, curang, berkhianat, dengki, iri, ria, tamak dan segala jenis perbuatan yang dipandang dosa. Pelaksananya pada tingkatan ini merupakan anggota biasa di dalam masyarakat.

b) Niyama-yoga, melatih dan membiasakan diri melakukan segala perbuatan yang bersifat kebaikan dan kebajikan. Pelaksananya pada tingkatan ini merupakan anggota biasa di dalam masyarakat.

c) Asana-yoga, memilih dan menentukan sikap tubuh tertentu bagi meditasi. Pada tingkatan ini seseorang telah memilih tempat tertentu bagi meditasi tersebut.

d) Pranayama-yoga, menahan nafas dalam sikap tubuh tertentu pada saat meditasi. Sifatnya bertahap sampai kemudian mampu menahan nafas dalam jangka waktu yang panjang. e) Pracahara-yoga, meniadakan pengaruh indra atas pengaruh apapun yang berada di sekitar diri sampai semuanya dipandang tidak ada sama sekali.

\section{Raja-yoga}

a. Dharana-yoga, pemusatan pikiran atas satu titik sassaran, yaitu Brahman, tanpa tergetar oleh apapun.

b. Dhyana-yoga, renungan rohani yang terus menerus terhadap titik konsentrasi, yaitu Brahman, tanpa ada ingatan lainnya.

c. Samadhi, mencapai titik ekstasi hingga pada saat itu bersatulah Atman dengan Brahman, yang di dalam agama Brahman/Hindu dirumuskan dengan "Dia adalah Aku, Aku adalah Dia" (Tattwam Asi).

Demikianlah tahap-tahap yang harus dilewati di dalam yoga. Namun tidak semua orang bisa mencapai tingkat raja-yoga, karena tahap-tahap di dalam kriya-yoga saja sudah demikian berat untuk bisa diselesaikan dengan baik dan sempurna. Dikatakan bahwa hanya orang-orang tertentu yang dapat mencapai tahapan raja-yoga.

Demikianlah Agama Hindu sangat menjunjung tinggi sila (etika). Kitab Wrehaspati Tattwa meletakkan sila nomor satu pada ajaran dharma bukanlah suatu kebetulan. Melainkan mempunyai arti strategis bahwa di antara tujuh bagian dharma (sila, yajna, tapa, dana, prawrejya, diksas, dan yoga) sila adalah yang pertama dan utama. Tanpa sila yang lain tak akan ada artinya dan tak akan berhasil. Hidup ini pun tak ada artinya bila tidak diemban dengan sila. Tak ada artinya kaya, sakti, jabatan tinggi, rupawan, dsb bila tanpa sila. Perilaku yang bertentangan dengan sila disebut asusila atau dursila akan menghilangkan nama baik bahkan jatuh menjadi nista (orang rendahan). Orang yang demikian hakekatnya mati walaupun masih bernapas dan kuat lincah. Lalu apa artinya kekayaan, jabatan tinggi, kesaktian, dll bila tanpa sila. "Sila ktikang predhana ring dadi wwang", yang artinya 
kemulyaan orang terletak pada silanya. Bila sila (etika) baik, walaupun ia berasal dari kalangan masyarakat bawah miskin, kurang pintar, masih muda, dia adalah orang mulia yang patut dihormati. Sebaliknya walaupun ia dari bangsawan tinggi kaya pintar, jabatan tinggi, sakti berumur, tapi asusila/dursila sesungguhnya dia orang rendahan dan tak patut dihormati.

Pada zaman krtha yuga, manusia sangat mulia dan yang diutamakan pada zaman ini adalah tapa disebutkan "Tapah param kertha yuge", artinya tapa adalah yang paling utama pada zaman krtha yuga; siapa yang lebih mampu melakukan tapa (mengendalikan diri) dia yang dianggap paling mulia dan paling dihormati.

Memang hasil tapa-brata itu sangat tinggi nilainya; hampir semua tokoh-tokoh Hindu seperti para Maha Rsi di zaman yang lampau lahir dari tapa brata, maksudnya menjadi besar dan sangat mulia karena hasil tapanya. Namun Bhagawan Brgu tetap meletakkan sila sebagai yang terbaik. Artinya : "Sarwasya tapasomulam acaram jagrhuh param" Dari semua hasil tapa brata dan lain sebagainya, tetap perbuatan baik (sila) adalah yang terbaik.

Fenomena tersebut di atas, maka etika atau susila Agama Hindu sebagai landasan mental spiritual pendidik yang profesional memiliki makna yang sangat luas. Etika atau susila Agama Hindu sebagai landasan mental spiritual pendidik yang profesional ada tiga langkah yang penting diperhatikan yang disebut dengan trikaya parisudha. Trikaya parisudha adalah tiga langkah yang harus disesuaikan agar dapat mencapai tujuan yang maksimal.

Bagian yang pertama adalah manacika, artinya berpikir yang baik. Untuk berpikir yang baik dan sesuai dengan etika atau susila Hindu ada tiga yang perlu diperhatiakan yakni: (a) tidak ingin dan dengki pada kepunyaan orang lain (iri hati); sesungguhnya sifat iri hati itu tidak baik (pandangan yang negatif), namun dalam pandangan yang positf iri hati itu penting untuk memacu semangat individu atau pribadi, dengan sikap iri hati akan timbul semangat dalam mencapai tujuan atau citacita. (b) tidak bersikap gemas kepada segala makhluk, yang artinya bahwa semua makhluk hidup itu memiliki hak untuk hidup bersama dalam komunitasnya. (c) percaya akan kebenaran ajaran karmaphala. Artinya bahwa segala tindakan pikiran yang dilakukan walaupun Cuma dalam pikiran tentu akan berbuah atau berakibat sesuai dengan baik buruknya pikiran. Apabila dipikirkan dengan baik maka hasilnya atau akibatnyapun akan baik juga, dan sebaliknya bila dipikirkan buruk akan berakibat buruk juga.

Kedua Wacika yang artinya perkataan baik. Sebagai seorang pemimpin profesional untuk menyampaikan segala sesuatu dengan perketaan hendaknya berkata yang sopan, lemah lembut, menyenangkan, dan tidak menyakiti hati bagi rang yang mendengarkannya. Dalam kitab Sarasamuscaya ada disebutkan emat jenis tentang larangan dalam berucap atau berkatakata yakni: (a) perkataan jahat; berkata jahat maksudnya tidak memanas-manasi suatu persoalan dan tidak membicarakan orang atau menjelek-jelekkan orang dan lain sebagainya. (b) perkataan kasar; maksudnya menyampaikan segala sesuatu hendaknya dengan kata-kata yang tidak membuat orang tersinggung, dan sebagai seorang pemimpin memiliki kode etik, sopan santun dan tahu tata krama berbicara sekalipun dalam kondisi yang tidak kondusip. (c) perkataan menghardik artinya bahwa berbicaralah dengan lemah lembut, jangan berbicara menggunakan kekuasaan dan wewenang. (d) perkataan bohong maksudnya secara umum bahwa memberikan suatu informasi harus pasti dan tidak boleh ragu-ragu, tidak boleh mengada-ada, tidak boleh memfitnah.

Ketiga Kayika yaitu berbuat atau bertindak yang baik. Dalam kitab Sarasamuscaya disebutkan ada tiga hal yang tidak boleh dilakukan yaitu. (a) membunuh: membunuh dalam pengertian yang sebenarnya adalah menghilangkan nyawa makhluk hidup. Tetapi etika sebagai landasan mental spiritual kepemimpinan Hindu yang profesional memiliki makna yang luas yakni tidak menghilangkan semangat masyarakat 
atau anggota organisasi. Dan jangan memotong pembicaraan orang dalam berdiskusi. Di samping itu membunuh pun dibenarkan dalam ajaran agama Hindu dan diatur dalam kehidupan beragama yakni: membunuh dibenarkan untuk kepentingan yadnya, kepentingan umum, kepentingan kehidupan, dan untuk disuguhkan kepada para tamu. Pembunuhan disini bukan semata-mata menghilangkan jiwa atau nyawa makhluk hidup tetapi memiliki makna lebih yaitu bertujuan meningkatkan jiwa kerohanian makhluk hidup tersebut. Sebagai pemimpin yang profesional bukan semata-mata menghilangkan rencana masyarakat atau anggota organisasi namun mampu untuk meberikan soslusi yang lebih baik untuk mencapai tujuan bermasyarakat atau berorganisasi. (b) mencuri: mencuri dalam pengertian yang sebenarnya adalah mengambil milik orang lain tanpa sepengetahuan orang yang punya. Sebagai seorang pemimpin yang profesional hendaknya tidak melaukkan tindakantindakan yang dapat merugikan orang lain dan diri sendiri, misalnya tidak melakukan korupsi, tidak melakukan pemotongan gajih karyawan yang tidak semestinya dan lain sebagainya. (c) berbuat zina artinya melakukan hubungan suami istri di luar pernikahan resmi atau hubungan suami istri yang tidak sah.

\section{PENUTUP}

Makna landasan mental spiritual pendidik yang profesional di zaman milenial bertujuan untuk mengendalikan emosi dan tingkah laku dalam menjalankan tugas-tugas kependidikan. Sikap seorang pendidik yang profesional, memiliki lima dasar kepercayaan yang disebut dengan Panca Sradha. Agama Hindu sangat menjunjung tinggi sila (etika) sebagai pedoman dalam bertingkah laku. Etika atau susila Agama Hindu sebagai landasan mental spiritual pendidik yang profesional ada tiga perbuatan penting diperhatikan yang disebut dengan Trikaya Parisudha. Trikaya Parisudha bagi pendidik profesional adalah tiga gerak/langkah yang harus disesuaikan agar dapat mencapai tujuan yang maksimal yaitu untuk memimpin perkembangan jasmani dan rohani peserta didik ke arah kedewasaan.

\section{DAFTAR PUSTAKA}

Aunurrahman. 2019. Belajar dan Pembelajaran. Bandung: Alfabeta.

Jalaludin dan H. Abdulah Ali. 2017. Filsafat Pendidikan: Manusia, Filsafat, dan Pendidikan.

Kajeng, I Nyoman, DKK. 2005. Sarasamuccaya Dengan Teks Bahasa Sansekerta dan Jawa Kuna. Surabaya. Paramita.

Keraf, A.Sonny.2002. Etika Lingkungan. Jakarta. Penerbit Buku Kompas.

Mufid, Muhamad. 2009. Etika dan Filsafat Komunikasi. Jakarta: Kencana Pranada Media Group.

Poerwadarminta,W.J.S. 2007. Kamus Umum Bahasa Indonesia. Jakarta. Balai Pustaka.

Pudja, G. 1988 Sarasamuscaya. Jakarta. Departemen Agama RI.

Pudja, G.2004. Bhagavadgìtà (Pañcama Veda). Surabaya. Paramita.

Pupu Saeful Rahmat. 2018. Psikologi Pendidikan. Jakarta: Bumi Aksara.

Putra, I. G. A. G. dan Sadia, I Wayan. 1998. Wrhaspati Tattwa (Alih Bahasa).

Putu Sanjaya. 2010. Acara Agama Hindu. Surabaya: Paramita.

Ritzer G. dan Goodman D.J. 2003. Teori Sosiologi Modern. Terjemahan Alimandan. Jakarta: Prenada Media Group.

Sanjaya, Wina. 2016. Strategi Pembelajaran Berorientasi Standar Proses Pendidikan. Jakarta: Prenadamedia Group.

Subagiasta, I Ketut. 2009. Reformasi Agama Hindu Dalam Perubahan Sosil di Bali 1950 - 1959. Surabaya. Paramita.

Subagiasta, I Ketut. 2010. Kepemimpinan Hindu Dalam Lontar Wrati Úàsana. Surabaya. Pàramita Surabaya.

Sugiyono. 2017. Metode Penelitian Kuantitatif, Kualitatif, dan R\&B. bandung: Alfabeta. 
Suprayogo Iman dan Tobroni. 2001. Syarief, Akhmad. 2012. Etika Profesi Metodologi Penelitian SosialAgama. Bandung: Remaja Rosdakarya Remaja PRESSindo. Yogyakarta. LaksBang Tim Penyusun. 1991. Kamus Besar Bahasa Suseno, Franz Magnis. 2000. 12 Tokoh Etika Abad ke-20. Yogyakarta. Penerbit Kanisius.

Syah, Muhibbin. 2015. Psikologi belajar. Depok: PT Rajagrafindo Persada. Indonesia. Jakarta: Bali Pustaka.

Zainal Abidin. 2009. Filsafat Manusia: Mengenal Manusia Melalui Filsafat. Bandung: PT Remaja Rosdakarya. 